\title{
Reading Comprehension Strategy (CSR) and Learners' Comprehension: A Case Study of FLD Students
}

\author{
Abdulamir Alamin ${ }^{1} \&$ Sawsan Ahmed ${ }^{1}$ \\ ${ }^{1}$ English Language Center, Taif University, KSA. \\ Correspondence: Abdulamir Alamin \& Sawsan Ahmed, English Language Center, Taif University, KSA. E-mail: \\ alamin@tu.edu.sa \\ Received: September 27, 2014 \\ Accepted: October 11, 2014 \\ Online Published: October 13, 2014 \\ doi:10.5430/elr.v3n2p64 \\ URL: http://dx.doi.org/10.5430/elr.v3n2p64
}

\begin{abstract}
The purpose of this study is to investigate the effect of Strategic Reading, specifically the Collaborative Strategic Reading (CSR) on Taif University. The participants are students from classes of English at the Department of Foreign Languages, of Arts College. The data mainly came from statistical results, including the questionnaire responses. The findings of CSR will be explored to find out the effect, positive or negative on the Taif university learners' reading comprehension particularly in relation to the comprehension questions on getting the main idea and finding the supporting details. The findings of the study will be used to suggest implementing better comprehension strategy instruction for the learners to adopt some degree of strategic reading behaviours, and to take long-term efforts and practices for EFL learners to fully develop their strategic reading abilities.

The present paper is an effort to deliver a base for better understanding the relationship between reading comprehension and reading strategies. The results of this paper will be implemented for better reading strategy instruction at Taif University, KSA.
\end{abstract}

Keywords: Comprehensions strategy instruction, Collaborative strategic reading (CSR), Reading comprehension

\section{Literature Review}

ESL researchers have stressed the importance of training language learners to perform as conscious readers. Paris et al. (1983) emphasized that developmental inability or poor learning can cause failure to enhance learning to be a strategic reading, which will not promote reading comprehension, and "failure to be a strategic (p.293). Palincsar \& Brown (1984) recommend that strategic reading helps students, especially low-achieving learners, avoid comprehension breakdown and improve their preservation of the text. Koda (2004) highlight that strategic reading can not only make up for learners' comprehension shortage but also increase their vital thinking. Pressley (2006) thinks that second language learners should go through be taught strategic reading all the way through overt instruction. Janzen \& Stoller (1998) continue saying that strategic reading instruction is worthwhile to both second language learners and their instructors. They argue that it enhance learners' independence and self-understanding of the meaning constructing development and it also get ready students for academic tasks. They also point out that reading strategy instruction provides a resourceful technique for teachers to motivate students' participation in their learning and teach them how to read efficiently.

Though a large number of research, such as of Huang, 2004; Klingner et al., 1998; Standish, 2005; Wang, 2008, have supported the positive impact of CSR on primary and secondary ESL and EFL learners' reading comprehension, learning motivation and English acquisition - but not in any EFL university settings. This would give a chance for a research to be conducted on the Taif University students. Questions rose whether younger learners rather than adult learners such as university students favours CSR? Or, Is CSR a practical approach to any community college or technical reading instruction? To understand the practicability of CSR with adult EFL learners, research is needed to bridge the gap. Thus, the purpose of this present study is to examine the effect of CSR on Taif university students' reading comprehension with reference to specific types of reading comprehension questions. It is hoped that this study can contribute to the understanding of CSR for university English educators who are anxious to increase their inventory of reading instruction models in their own contexts.

Klingner et al. (1998) proposed Collaborative Strategic Reading (CSR), as one type of comprehension strategy instruction not only useful but necessary to help students become strategic readers and more self-regulated learners. 
In CSR, students are trained into four reading strategies. They are : including "preview", "click and clunk", "get the gist" and "wrap-up". Research of (Huang, 2004; Klingner et al., 1998; Standish, 2005; Wang, 2008) have supported the positive impact of CSR on primary and secondary ESL and EFL learners' reading comprehension, learning motivation and English acquisition, but not in any EFL university settings. This would give a chance for a research whether younger learners, rather than adult learners such as university students, favour the CSR? Or Is CSR a practical approach to technical training institutes or community colleges, reading instruction? To understand the feasibility of CSR with adult EFL learners, research is needed to bridge the gap. Thus, the purpose of this present study is to examine the effect of CSR on Taiwanese university learners' reading comprehension with reference to specific types of reading comprehension questions. It is hoped that this study can contribute to the understanding of CSR for university English teachers who are interested in increasing their repertoire of reading instruction models in their own contexts.

Palincsar \& Brown (1984) proposed the Reciprocal teaching (RT) as one of the most influential approaches. Reciprocal teaching is designed for students who have basic skills but have difficulties in meaning construction. Using reciprocal teaching, students gradually take the role of the teacher, when they become more capable. This aims to make them more self-regulating and independent in their learning. According to Pressley (2002), this instructional model involves teachers' and students' reciprocated work to build up text meaning. In practice, teachers form four cognitive reading strategies by using the 'thinking aloud technique' to help students improve their reading comprehension: 'summarizing', 'generating questions', 'clarifying', and 'making predictions'. In classroom settings using reciprocal teaching, students gradually assume the role of being "the teacher" when they become more proficient. This aims to make them more independent in their learning.

Studies of Rosenshine \& Meister (1994) were quantitative in nature and involved control and experimental groups. The results of mixed abilities, good in decoding but poor in comprehension, below average showed that the studies using researcher-developed comprehension measures had a greater impact than the ones with standardized reading tests. The findings concluded that students who benefit the most are those who are good at decoding but poor at comprehension. Song (1998) found that reciprocal teaching helps university students improve their reading comprehension particularly in the understanding of main ideas and making inferences of the given passages. Cotterall (1990) found that learners in a reciprocal pre-university ESL class, teaching became better in searching for the main ideas from the texts and activating their background knowledge. Chen (2005) concludes in his research of the effects of a modified model of comprehension strategy instruction similar to RT on senior school students' reading comprehension, that comprehension strategy instruction helped the subjects increase their ability in getting main ideas, making inferences and finding answers for detailed questions.

Chen (2005), Cotterall (1990) and Song (1998) did not include a control group. In spite of the fact that their findings may be seen as analytical in establishing the effectiveness of reciprocal teaching, but they do not show any comparison between those who do and those who do not receive this reading approach. Moreover, most studies do not show how students actually construct meaning with a short experimental period. Therefore, more qualitative research would be helpful to provide a holistic evaluation.

Roehler \& Duffy (1984) emphasized on the important role of the teacher in guiding and helping the learners to understand reading comprehension. Hence, teachers explains what the strategies are, and when and how to use them. Teachers' feedback is reduced as students become more independent in using reading strategies. This study shows that less able students who receive direct explanation of comprehension strategies show positive improvement in understanding and reading achievement.

In another comprehension intervention proposed by Pressley et al. (1992).He proposed transactional strategies instruction (TSI). This strategic reading intervention shares the same features of teacher modeling, direct explanation of reading strategies and guided practice with direct explanation of comprehension strategies.

Pressley (2002) sees the major difference between TSI and other comprehension strategy approaches is that TSI not only emphasizes cognitive reading strategies but also interpretative strategies. In TSI, a small list of comprehension strategies are instructed and practiced over a long period of time including predicting, generating images, seeking clarification and summarizing.

Loranger (1997) gathered Quantitative and qualitative data including pre/post-test on a standardized reading test, pre/post interviews, videotaped reading discussions and response journals. The findings of this study supported the positive impact of TSI on young learners' reading achievement. 
It would be interesting to mention the work of Klingner et al. (1998). This study consisted of experimental and control groups. The control groups received teacher-led reading instruction without the introduction of the four reading comprehension strategies and group work. The four reading strategies were mentioned and introduced in the experimental group. Students were engaged in peer-led discussions to help them improve their reading comprehension. The experiment lasted 11 days. The findings of this study suggest that students in the experimental groups did better than of the control groups in terms of reading comprehension, but did not show any major difference in content learning.

Standish (2005) examined how CSR in combination with direct instruction in persuasion affected learners' persuasive writing. This study concluded that the students in the group of CSR outperformed significantly and found to engage more actively in the writing tasks. Lee (2003) compared the effect of CSR and the traditional teacher-dominated approach on students' reading comprehension and vocabulary learning. The statistical results showed that CSR was very useful to the students in improve their reading comprehension more than traditional instruction, but it did not show any improvement in terms of phoneme correspondence and word recognition.

Huang (2004) looked into the practicability and worth of CSR in question-based methodology to improve high school students' strategic reading and develop their critical thinking ability. This study involved EFL learners. The quantitative results originated from periodic achievement tests showed that the CSR group did not significantly outperform the control group. CSR was helpful in developing students' critical thinking and writing ability in terms of content and idea exploration as shown by the qualitative data analysis of the writing samples. A majority of the participants considered the CSR as an effective method to promote their autonomous learning and social skills.

\section{Methodology and Procedures}

\subsection{Participants}

This study is carried out at the Foreign Languages Department of the College of Arts, Taif University. First year is a preparatory study at the University. One hundred and thirty-four University Students $(\mathrm{N}=134)$ participated in this study: 79 male students and 55 female students. There are three sections, Literary, Scientific and Health. Literary Stream students study five courses each semester. They take English Language I for the first semester, and English Language II, for the second semester, in the English Language Centre. Credit hours are12-15 each. The main learning outcomes for students enrolled in the course, as mentioned in the National Commission for Academic Accreditation \& Assessment - Course Specification- are that by the end of the semester, students are expected to exhibit knowledge of reading strategies for the comprehension of a text with some unfamiliar vocabulary, and understand and answer questions on passages, including information about past and current events; Approximately 390-438 study hours are expected per semester as an additional private study/learning hours and 21-28 hours are expected from students per week. Students will be accepted to the Department based on FLD requirement of the GPA, and capacity of the Department. All students are grouped unfortunately into one class level. There are no advanced, intermediate and elementary levels of English. The participants had at least 6 years of English school learning besides the one year preparatory. Due to administrative constrains, the researcher were able to secure consent to the classes but not to have control group and experimental groups. All of the research participants are senior students majoring English language at the FLD. They are 79 boys and 55 girls from levels 7 and 8 .

\subsection{The Reading Materials}

The reading materials used in the present study are the CSR Model Lesson used Colorado which is a leading-edge initiative that brings the unique approach of Collaborative Strategic Reading to the middle schools of Denver. Reading lesson plans were designed by a team of district curriculum coordinators, Colorado staff, University of Colorado.

Every lesson plan included all the resources and information a teacher would need to effectively teach a lesson using the strategies - essential key vocabulary as well as video-clips and pictures to illustrate the words; possible clunks; gist and review statements; and explicit connections to curriculum.

Readings for each lesson are selected from the curriculum or supplemental readings aligned with the ideas and key concepts of each unit of study. Each lesson plan details intended content outcomes and highlights potential opportunities for emphasis on reading strategy practice (Sharon, 2011).

\subsection{The Questionnaire Procedures}

To gather data regarding the FLD students' perspectives on CSR, a questionnaire was administered to the students, male and female. General procedures for this research consisted of (a) orientation session to the students for CSR. 
Two two-hour sessions were conducted to familiarize the students with the strategies and skills needed for the implementation of CSR. The researcher introduced the entire CSR by explaining the strategies so that students understood the overall picture.

The four comprehension strategies were explained to the students to provide an overview of how to implement the research study. Preview is the first strategy. Students were told to preview the entire passage before they read each section. The goals of previewing are (a) for students to learn as much about the passage as they can in a brief period of time (2-3 minutes), (b) to activate their background knowledge about the topic, and (c) to help them make predictions about what they will learn. Previewing serves to motivate students' interest in the topic and to engage them in active reading from the start. When students preview before reading, they should look at headings; words that are bolded or underlined; and pictures, tables, graphs, and other key information to help them do two things: (a) brainstorm what they know about the topic and (b) predict what they will learn about the topic. Just as in watching a movie preview, students are provided minimal time to generate their ideas and discuss their background knowledge and predictions.

I would give the students two minutes to write down everything they already know about a topic in their CSR Learning Logs. Students then would share their responses with one another for about 1 minute. Another two minutes are provided for students to write down their predictions of what they might learn, followed by 1 minute to share their best ideas.

Teach students the previewing strategy from the beginning of the school year and before they read aloud or silently is very good strategy. Like most of the CSR strategies, it might be applied across the curriculum. By using previewing in different subject areas, students become highly familiar with the strategy and its use. They will also have had opportunities to watch and apply the strategy with the class as a whole, making its implementation in small groups easier.

The second strategy is Click and clunk. Students click and clunk while reading each section of the passage. The goal of clicking and clunking is to teach students to monitor their reading comprehension and to identify when they fail understanding. Clicks refer to portions of the text that make sense to the reader: "Click, click, click" comprehension clicks into place as the reader proceeds smoothly through the text. When a student comes to a word, concept, or idea that does not make sense, "Clunk" - comprehension breaks down. For example, when students do not know the meaning of a word, it is a clunk.

Many students with reading and learning problems fail to monitor their understanding when they read. Clicking and clunking is designed to teach students to pay attention to when they understand - or failing to understand - what they are reading or what is being read to them. The teacher asks, "Is everything clicking? Who has clunks about the section we just read?" Students know that they will be asked this question and are alert to identify clunks during reading.

After students identify clunks, the class uses "fix-up" strategies to figure out the clunks. Students are encouraged to use "clunk cards" as prompts to remind them of various fix-up strategies. On each of the clunk cards is printed a different strategy for figuring out a clunk word, concept, or idea:

- $\quad$ Reread the sentence without the word. Think about what information that is provided that would help you understand the meaning of the word.

- $\quad$ Reread the sentence with the clunk and the sentences before or after the clunk looking for clues.

- $\quad$ Look for a prefix or suffix in the word.

- $\quad$ Break the word apart and look for smaller words you know.

As with the other strategies, you may teach students the click and clunk strategy from the beginning of the year and use it in various contexts. Students apply these fix-up strategies at first with help from the teacher and then in their small groups.

Get the gist is the third strategy of the CSR. Students learn to "get the gist" by identifying the most important idea in a section of text (usually a paragraph). The goal of getting the gist is to teach students to re-state in their own words the most important point as a way of making sure they have understood what they have read. This strategy can improve students' understanding and memory of what they have learned: First, prompt the students to identify the most important person, place, or thing in the paragraph they have just read. Then, ask them to tell you in their own words the most important idea about the person, place, or thing. Teach students to provide the gist in as few words as possible while conveying the most meaning, leaving out details. 
Strategy 4 is the wrapping up stage. The goals are to improve students' knowledge, understanding, and memory of what was read. The best way to teach wrap up is to tell students to use the following question starters to begin their questions: who, what, when, where, why and how (the $5 \mathrm{Ws}$ and an $\mathrm{H}$ ). Teach students to ask some questions about information that is stated explicitly in the passage and other questions that require an answer not right in the passage. Encourage students to ask questions that involve higher-level thinking skills. To facilitate students' ability to generate higher-level questions, the following questions can be provided:

How were ___ and ___ the same? Different?

What do you think would happen if ?

The students' roles

Student roles are an important aspect of CSR because cooperative learning seems to work best when all group members have been assigned a meaningful task. Possible roles include the following:

\section{Leader}

This student leads the group in the implementation of CSR by saying what to read next and what strategy to apply next. The leader asks the teacher for assistance, if necessary.

\section{Clunk expert}

This student uses clunk cards to remind the group of the steps to follow when trying to figure out a difficult word or concept.

\section{Announcer}

This student calls on different group members to read or share an idea. He or she makes sure everyone participates and only one person talks at a time.

\section{Encourager}

This student watches the group and gives feedback. He or she looks for behaviors to praise. The student encourages all group members to participate in the discussion and assist one another. He or she evaluates how well the group has worked together and gives suggestions for improvement.

\section{Reporter}

During the whole-class wrap-up, this student reports to the class the main ideas the group learned and shares a favorite question the group has generated.

\section{Time keeper}

This student sets the timer for each portion of CSR and lets the group know when it is time to move on (the teacher might do this instead of students).

The teacher's role in the CSR is to circulate among the groups and provide ongoing assistance, and listening to students' conversations clarifying difficult words, if necessary, encouraging students to participate (Klingner, et al.2002).

After an overall description of the practice, the researcher provided explicit instruction on how to use each strategy. (b) Pretesting and post testing. At pretest and posttest, the researcher collected quantitative date to assess the participants' comprehension. The pretest was conducted one hour prior to the beginning of the implementation of CSR, while the posttest tool place during the reading class immediately following the completion of the CSR session. The same reading passages and comprehension questions were administered in the pretest and posttest. The main reason for using the same questions was to ensure that they were exactly comparable.

The reading strategies were explained to the students before any forms were given to the students.

The questionnaire composed of Likert scale statements. The participants were requested to indicate the extent to which they agreed with each statement using

(1) Strongly disagree, (2) disagree, (3) no opinion, (4) agree, and (5) strongly agree.

The questionnaire was given to a couple of senior staff who taught reading courses before for validation and reliability. They reviewed the questions. They thought some of the questions were either not clear or repetitive. Once this established, the questionnaire was given to the students to answer them followed by analysis and discussion of these answers. 


\section{Discussion}

A Paired T-Test was conducted to compare the Mean difference of Students prior to the Reading Comprehension Strategy as well as post- Reading Comprehension Strategy. (Pre-Reading Strategy Test ( $M=2.517, \mathrm{SD}=0.453$ ), Post Reading Strategy test $(\mathrm{M}=2.452, \mathrm{SD}=466)$ (see Table 1).

Table 1. Paired T-Test: Pre-Reading Strategy vs Post-Reading Strategy

Paired Samples Statistics

\begin{tabular}{|c|c|c|c|c|c|c|}
\hline & & ean & $\mathrm{N}$ & Std. Deviation & Std. Er & \\
\hline \multirow{2}{*}{ Pair 1} & MeanPre & 2.5167 & 134 & .45333 & & .03916 \\
\hline & MeanPost & 2.4519 & 134 & .46559 & & .04022 \\
\hline \multicolumn{7}{|c|}{ Paired Samples Correlations } \\
\hline & & & $\mathrm{N}$ & Correlation & Sig. & \\
\hline Pair 1 & MeanPre 8 & & 134 & .497 & .000 & \\
\hline
\end{tabular}

Our Null Hypothesis is that the Reading Strategy Survey was not effective. The alternative hypothesis is that the Reading strategy was effective for the participants.

Since the P-Value is 0.106 , we reject the alternative hypothesis and conclude that the Reading Strategy Survey was not effective at $5 \%$ significance level.

Pre-Reading Strategy Test $(\mathrm{M}=2.517, \mathrm{SD}=0.453)$ and Post Reading Strategy test $(\mathrm{M}=2.452, \mathrm{SD}=466 \mathrm{t}=(133)=$ $1.628, \mathrm{p}=0.106$ (see table 2).

Table 2. Paired T-Test: Pre-Reading Strategy vs Post-Reading Strategy

Paired Samples Test

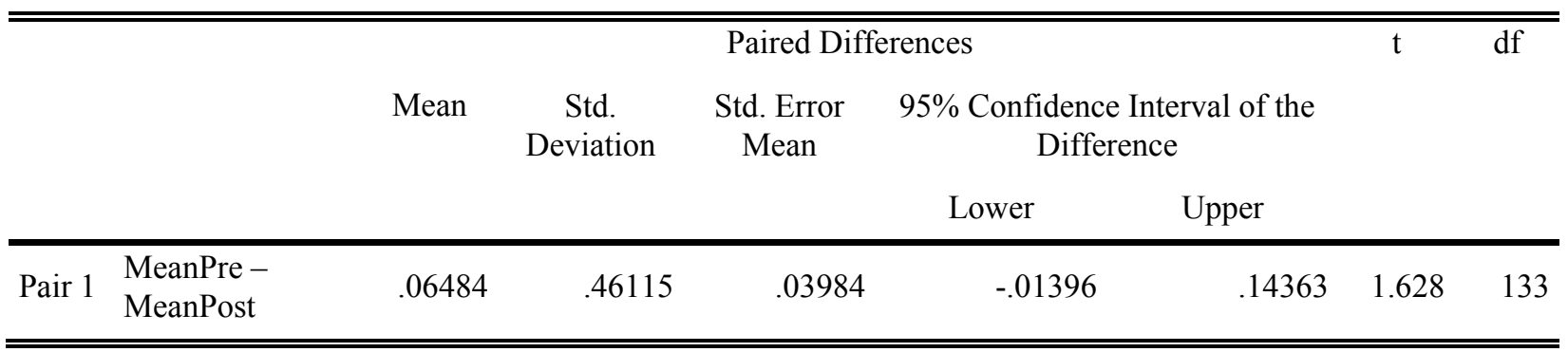

Paired Samples Test

Sig. (2-tailed)

\begin{tabular}{lll}
\hline Pair 1 & MeanPre - MeanPost & .106 \\
\hline
\end{tabular}

An analysis was conducted on Types of Comprehension Questions imbedded in the Reading Strategy Questionnaire. One-Way ANOVA was conducted to determine if there were statistical differences between the types of questions and the gender of the participants. Tables 3 and 4 illustrate the results, there was a statistical significance for four the five Types of Questions (Predicting $\mathrm{F}=17.013, \mathrm{p}=0.000<0.05$, Getting the main idea $\mathrm{F}=6.276, \mathrm{p}=.013<.05$, finding the supporting details $\mathrm{F}=.021, \mathrm{p}=.848>.05$, dealing with vocabulary $\mathrm{F}=14.840, \mathrm{p}=.000<.05$, and making inferences $\mathrm{F}=9.261, \mathrm{p}=.03<.05)$. 
Table 3. One way ANOVA-Gender Differences

\begin{tabular}{|c|c|c|c|c|c|c|}
\hline & & Sum of Squares & $\mathrm{df}$ & Mean Square & $\mathrm{F}$ & Sig. \\
\hline \multirow{3}{*}{ Predicting } & Between Groups & & 1 & 10.439 & 17.013 & .000 \\
\hline & Within Groups & 80.994 & 132 & .614 & & \\
\hline & Total & 91.433 & 133 & & & \\
\hline \multirow{3}{*}{ Getting The Main Idea } & Between Groups & 3.117 & 1 & 3.117 & 6.276 & .013 \\
\hline & Within Groups & 65.571 & 132 & .497 & & \\
\hline & Total & 68.689 & 133 & & & \\
\hline \multirow{3}{*}{ Finding the Supporting Details } & Between Groups & .016 & 1 & .016 & .021 & .884 \\
\hline & Within Groups & 100.312 & 132 & .760 & & \\
\hline & Total & 79.1 & 133 & & & \\
\hline \multirow{3}{*}{ Dealing With Vocabulary } & Between Groups & 13.384 & 1 & 13.384 & 14.840 & .000 \\
\hline & Within Groups & 119.051 & 132 & .902 & & \\
\hline & Total & 132.435 & 133 & & & \\
\hline \multirow{3}{*}{ Making Inferences } & Between Groups & 6.037 & 1 & 6.037 & 9.261 & .003 \\
\hline & Within Groups & 86.040 & 132 & .652 & & \\
\hline & Total & 92.077 & 133 & & & \\
\hline
\end{tabular}

Table 4. Descriptive One-WAY ANOVA

\begin{tabular}{|c|c|c|c|c|c|c|c|c|c|}
\hline \multicolumn{10}{|c|}{ Descriptive } \\
\hline & & \multirow[t]{2}{*}{$\mathrm{N}$} & \multirow[t]{2}{*}{ Mean } & \multirow[t]{2}{*}{$\begin{array}{c}\text { Std. } \\
\text { Deviation }\end{array}$} & \multirow[t]{2}{*}{$\begin{array}{l}\text { Std. } \\
\text { Error }\end{array}$} & \multicolumn{2}{|c|}{$\begin{array}{c}\text { 95\% Confidence } \\
\text { Interval } \\
\text { for Mean }\end{array}$} & \multirow[t]{2}{*}{ Minimum } & \multirow[t]{2}{*}{ Maximum } \\
\hline & & & & & & $\begin{array}{l}\text { Lower } \\
\text { Bound }\end{array}$ & $\begin{array}{l}\text { Upper } \\
\text { Bound }\end{array}$ & & \\
\hline \multirow[t]{3}{*}{ Predicting } & male & 79 & 2.7553 & .87333 & .09826 & 2.5597 & 2.9509 & 1.33 & 5.00 \\
\hline & female & 55 & 2.1879 & .63103 & .08509 & 2.0173 & 2.3585 & 1.00 & 4.00 \\
\hline & Total & 134 & 2.5224 & .82914 & .07163 & 2.3807 & 2.6641 & 1.00 & 5.00 \\
\hline \multirow[t]{3}{*}{ Getting the Main Idea } & male & 79 & 2.4873 & .74021 & .08328 & 2.3215 & 2.6531 & 1.00 & 4.75 \\
\hline & female & 55 & 2.1773 & .65027 & .08768 & 2.0015 & 2.3531 & 1.00 & 3.75 \\
\hline & Total & 134 & 2.3601 & .71865 & .06208 & 2.2373 & 2.4829 & 1.00 & 4.75 \\
\hline \multirow{3}{*}{$\begin{array}{l}\text { Finding the Supporting } \\
\text { Details }\end{array}$} & male & 79 & 2.2595 & .88020 & .09903 & 2.0623 & 2.4566 & 1.00 & 4.50 \\
\hline & female & 55 & 2.2818 & .85939 & .11588 & 2.0495 & 2.5141 & 1.00 & 5.00 \\
\hline & Total & 134 & 2.2687 & .86853 & .07503 & 2.1203 & 2.4171 & 1.00 & 5.00 \\
\hline \multirow{3}{*}{$\begin{array}{l}\text { Dealing With } \\
\text { Vocabulary }\end{array}$} & male & 79 & 2.7152 & 99899 & .11239 & 2.4914 & 2.9390 & 1.00 & 5.00 \\
\hline & female & 55 & 2.0727 & .87357 & .11779 & 1.8366 & 2.3089 & 1.00 & 5.00 \\
\hline & Total & 134 & 2.451 & .99787 & .08620 & 2.2810 & 2.6220 & 1.00 & 5.00 \\
\hline \multirow{4}{*}{ Making Inferences } & & & 5 & & & & & & \\
\hline & male & 79 & 2.5633 & .81401 & .09158 & 2.3810 & 2.7456 & 1.00 & 5.00 \\
\hline & female & 55 & 2.1318 & .79764 & .10755 & 1.9162 & 2.3475 & 1.00 & 4.50 \\
\hline & Total & 134 & 2.3862 & .83205 & .07188 & 2.2440 & 2.5284 & 1.00 & 5.00 \\
\hline
\end{tabular}


An analysis using an Independent T-Test reveals a statistical significance between gender and Pre-Test means (see Tables 5 and 6 ).

Table 5. Independent T-Test: Gender differences in Pre-Reading Strategy Questionnaire

Group Statistics

\begin{tabular}{llllrr}
\hline \hline & Gender & $\mathrm{N}$ & Mean & Std. Deviation & Std. Error Mean \\
\hline \multirow{2}{*}{ MeanPre } & male & 79 & 2.6412 & .49311 & .05548 \\
& female & 55 & 2.3378 & .31569 & .04257 \\
\hline \hline
\end{tabular}

Table 6. Independent T-Test: Gender differences in Pre-Reading Strategy Questionnaire Independent Samples Test

\begin{tabular}{|c|c|c|c|c|c|c|c|}
\hline & & \multicolumn{2}{|c|}{$\begin{array}{c}\text { Levene's Test for Equality of } \\
\text { Variances }\end{array}$} & \multicolumn{4}{|c|}{ t-test for Equality of Means } \\
\hline & & $\mathrm{F}$ & Sig. & $\mathrm{t}$ & $\mathrm{df}$ & $\begin{array}{c}\text { Sig. } \\
\text { (2-tailed) }\end{array}$ & $\begin{array}{c}\text { Mean } \\
\text { Difference }\end{array}$ \\
\hline \multirow{2}{*}{ MeanPre } & $\begin{array}{l}\text { Equal variances } \\
\text { assumed }\end{array}$ & 7.772 & .006 & 4.022 & 132 & .000 & .30338 \\
\hline & $\begin{array}{l}\text { Equal variances not } \\
\text { assumed }\end{array}$ & & & 4.339 & 131.194 & .000 & .30338 \\
\hline
\end{tabular}

Independent Samples Test

t-test for Equality of Means

Std. Error Difference $\quad 95 \%$ Confidence Interval of the Difference

\begin{tabular}{llccc} 
& & Lower & Upper \\
\hline \multirow{2}{*}{ MeanPre } & $\begin{array}{l}\text { Equal variances assumed } \\
\text { Equal variances not } \\
\text { assumed }\end{array}$ & .07542 & .15419 & .45258 \\
& .06993 & .16505 & .44172
\end{tabular}

Specifically Question 8 of the Pre-test reveals a statistically significant difference in female responses to the question. "I believe my reading comprehension is improving over time".

More females strongly agree then males. Male $(M=2.11, S D=1.18)$ and Female $(M=1.72, S D=0.83)$

Group Statistics

\begin{tabular}{llllrr}
\hline & Gender & $\mathrm{N}$ & \multicolumn{1}{l}{ Mean } & Std. Deviation & \multicolumn{1}{c}{ Std. Error Mean } \\
\hline post8 & male & 79 & 2.2785 & 1.06141 & .11942 \\
\cline { 2 - 6 } & female & 55 & 2.0000 & 1.08866 & .14680 \\
\hline pre8 & male & 79 & 2.1139 & 1.17656 & .13237 \\
\cline { 2 - 6 } & female & 55 & 1.7273 & .82674 & .11148
\end{tabular}

$\mathrm{t}(132)=2.102, \mathrm{p}=0.37$. (see Table 7) 
Table 7. Gender differences Pre and Post- Reading Strategies

Independent Samples Test

\begin{tabular}{|c|c|c|c|c|c|c|c|c|c|c|}
\hline & & \multicolumn{2}{|c|}{$\begin{array}{c}\text { Levene's Test } \\
\text { for Equality of } \\
\text { Variances }\end{array}$} & \multicolumn{7}{|c|}{ t-test for Equality of Means } \\
\hline & & \multirow[t]{2}{*}{$\mathrm{F}$} & \multirow[t]{2}{*}{ Sig. } & \multirow[t]{2}{*}{$\mathrm{t}$} & \multirow[t]{2}{*}{$\mathrm{df}$} & \multirow[t]{2}{*}{$\begin{array}{c}\text { Sig. } \\
\text { (2-tailed) }\end{array}$} & \multirow[t]{2}{*}{$\begin{array}{c}\text { Mean } \\
\text { Difference }\end{array}$} & \multirow[t]{2}{*}{$\begin{array}{l}\text { Std. Error } \\
\text { Difference }\end{array}$} & \multicolumn{2}{|c|}{$\begin{array}{l}95 \% \text { Confidence } \\
\text { Interval of the } \\
\text { Difference }\end{array}$} \\
\hline & & & & & & & & & Lower & Upper \\
\hline \multirow[t]{2}{*}{ post8 } & $\begin{array}{l}\text { Equal } \\
\text { variances } \\
\text { assumed }\end{array}$ & .091 & .764 & 1.478 & 132 & .142 & .27848 & .18837 & -.09413 & .65110 \\
\hline & $\begin{array}{l}\text { Equal } \\
\text { variances } \\
\text { not } \\
\text { assumed }\end{array}$ & & & 1.472 & 114.427 & .144 & .27848 & .18923 & -.09637 & .65334 \\
\hline \multirow[t]{2}{*}{ pre8 } & $\begin{array}{l}\text { Equal } \\
\text { variances } \\
\text { assumed }\end{array}$ & 4.677 & .032 & 2.102 & 132 & .037 & .38665 & .18398 & .02271 & .75059 \\
\hline & $\begin{array}{l}\text { Equal } \\
\text { variances } \\
\text { not } \\
\text { assumed }\end{array}$ & & & 2.234 & 131.981 & .027 & .38665 & .17306 & .04432 & .72898 \\
\hline
\end{tabular}

However, Post-Reading Strategy reveals a decline in "strongly agree" responses. This could be due to their confidence decreasing after completing the reading strategy lesson and questionnaire. Male $(\mathrm{M}=2.28, \mathrm{SD}=1.06)$ and Female $(\mathrm{M}=2, \mathrm{SD}=1.09) \mathrm{t}(132)=1.478, \mathrm{p}=1.42)($ See Tables 8,9 , and 10)

Table 8. Independent T-Test: Gender differences in Reading Strategies

Group Statistics

\begin{tabular}{lllccc}
\hline \hline & Gender & $\mathrm{N}$ & Mean & $\begin{array}{c}\text { Std. } \\
\text { Deviation }\end{array}$ & Std. Error Mean \\
\hline \multirow{2}{*}{ MeanRS } & male & 79 & 2.6228 & .59894 & .06739 \\
& female & 55 & 2.4206 & .36602 & .04935 \\
\hline \hline
\end{tabular}

Table 9. Independent T-Test: Gender differences in Reading Strategies

Independent Samples Test

\begin{tabular}{llllllll}
\hline \hline & $\begin{array}{c}\text { Levene's Test for Equality of } \\
\text { Variances }\end{array}$ & & \multicolumn{3}{c}{ t-test for Equality of Means } \\
& F & Sig. & t & df & $\begin{array}{c}\text { Sig. } \\
\text { (2-tailed) }\end{array}$ & $\begin{array}{c}\text { Mean } \\
\text { Difference }\end{array}$ \\
\hline MeanRS & $\begin{array}{l}\text { Equal variances } \\
\text { assumed } \\
\text { Equal variances not } \\
\text { assumed }\end{array}$ & 13.158 & .000 & 2.229 & 132 & .028 & .20218 \\
\hline \hline
\end{tabular}


Independent Samples Test

\begin{tabular}{llrrr}
\hline \hline & & & t-test for Equality of Means \\
& & Std. Error Difference & 95\% Confidence Interval of the Difference \\
MeanRS & Equal variances assumed & & Lower & Upper \\
\hline \multirow{2}{*}{$\begin{array}{l}\text { Equal variances not } \\
\text { assumed }\end{array}$} & .09071 & .02275 & .38161 \\
\hline \hline
\end{tabular}

Table. 9. Independent T-Test: Gender differences in Post-Reading Strategies

Group Statistics

\begin{tabular}{|c|c|c|c|c|c|}
\hline & Gender & $\mathrm{N}$ & Mean & Std. Deviation & Std. Error Mean \\
\hline \multirow{2}{*}{ MeanPost } & male & 79 & 2.4708 & .51290 & .05771 \\
\hline & female & 55 & 2.4246 & .39070 & .05268 \\
\hline
\end{tabular}

Table 10. Independent T-Test: Gender differences in Post-Reading Strategies

Independent Samples Test

\begin{tabular}{|c|c|c|c|c|c|c|c|}
\hline & & \multicolumn{2}{|c|}{$\begin{array}{c}\text { Levene's Test for Equality of } \\
\text { Variances }\end{array}$} & \multicolumn{4}{|c|}{ t-test for Equality of Means } \\
\hline & & $\mathrm{F}$ & Sig. & $\mathrm{t}$ & Df & $\begin{array}{c}\text { Sig. } \\
\text { (2-tailed) }\end{array}$ & $\begin{array}{c}\text { Mean } \\
\text { Difference }\end{array}$ \\
\hline \multirow{2}{*}{ MeanPost } & $\begin{array}{l}\text { Equal variances } \\
\text { assumed }\end{array}$ & 2.927 & .089 & .563 & 132 & .574 & .04617 \\
\hline & $\begin{array}{l}\text { Equal variances } \\
\text { not assumed }\end{array}$ & & & .591 & 130.879 & .556 & .04617 \\
\hline \multicolumn{8}{|c|}{ Independent Samples Test } \\
\hline & & \multicolumn{6}{|c|}{ t-test for Equality of Means } \\
\hline & & \multirow{2}{*}{\multicolumn{2}{|c|}{ Std. Error Difference }} & \multicolumn{4}{|c|}{$95 \%$ Confidence Interval of the Difference } \\
\hline & & & & \multicolumn{2}{|c|}{ Lower } & \multicolumn{2}{|c|}{ Upper } \\
\hline \multirow[b]{2}{*}{ MeanPost } & Equal variances assumed & & .08198 & & -.115 & & .20833 \\
\hline & $\begin{array}{l}\text { Equal variances not } \\
\text { assumed }\end{array}$ & & .07814 & & -.108 & & .20075 \\
\hline
\end{tabular}

Pre-Reading Strategy, Question 19" I feel happy when I read now" was analyzed using an independent T-Test and found statistically significant difference between male and female responses (Tables 11, 12, and 13). 
Table 11. Gender differences Pre and Post- Reading Strategies

Group Statistics

\begin{tabular}{|c|c|c|c|c|c|}
\hline & Gender & $\mathrm{N}$ & Mean & Std. Deviation & Std. Error Mean \\
\hline \multirow{2}{*}{ pre19 } & male & 79 & 2.6709 & 1.17366 & .13205 \\
\hline & female & 55 & 2.1818 & .88382 & .11917 \\
\hline \multirow{2}{*}{ post19 } & male & 79 & 2.3797 & 1.11291 & .12521 \\
\hline & female & 55 & 2.2000 & 1.09545 & .14771 \\
\hline
\end{tabular}

Table12. Gender differences Pre and Post- Reading

Independent Samples Test

\begin{tabular}{|c|c|c|c|c|c|c|c|c|c|c|}
\hline & & \multicolumn{2}{|c|}{$\begin{array}{l}\text { Levene's Test for } \\
\text { Equality of Variances }\end{array}$} & \multirow{3}{*}{$\mathrm{t}$} & \multirow{3}{*}{ df } & \multicolumn{3}{|c|}{ t-test for Equality of Means } & & \\
\hline & & \multirow[t]{2}{*}{$\mathrm{F}$} & \multirow[t]{2}{*}{ Sig. } & & & \multirow[t]{2}{*}{$\begin{array}{c}\text { Sig. } \\
\text { (2-tailed) }\end{array}$} & \multirow[t]{2}{*}{$\begin{array}{c}\text { Mean } \\
\text { Difference }\end{array}$} & \multirow[t]{2}{*}{$\begin{array}{l}\text { Std. Error } \\
\text { Difference }\end{array}$} & \multicolumn{2}{|c|}{$\begin{array}{c}95 \% \\
\text { Confidence } \\
\text { Interval of the } \\
\text { Difference }\end{array}$} \\
\hline & & & & & & & & & Lower & Upper \\
\hline \multirow{2}{*}{ pre19 } & $\begin{array}{l}\text { Equal } \\
\text { variances } \\
\text { assumed }\end{array}$ & 6.589 & .011 & 2.616 & 132 & .010 & .48907 & .18697 & .11922 & .85891 \\
\hline & $\begin{array}{l}\text { Equal } \\
\text { variances } \\
\text { not assumed }\end{array}$ & & & 2.750 & 131.140 & .007 & .48907 & .17787 & .13719 & .84094 \\
\hline \multirow{2}{*}{ post19 } & $\begin{array}{l}\text { Equal } \\
\text { variances } \\
\text { assumed }\end{array}$ & .915 & .340 & .926 & 132 & .356 & .17975 & .19419 & -.20439 & .56388 \\
\hline & $\begin{array}{l}\text { Equal } \\
\text { variances } \\
\text { not assumed }\end{array}$ & & & .928 & 117.490 & .355 & .17975 & .19364 & -.20373 & .56322 \\
\hline
\end{tabular}

Table 13. Group Statistics for Pre-Reading Strategy

Group Statistics

\begin{tabular}{llrrrr}
\hline \hline & Gender & N & Mean & $\begin{array}{c}\text { Std. } \\
\text { Deviation }\end{array}$ & $\begin{array}{c}\text { Std. Error } \\
\text { Mean }\end{array}$ \\
\hline \multirow{2}{*}{ Pre1 } & Male & 79 & $\begin{array}{r}2.405 \\
1\end{array}$ & .89899 & .10114 \\
& Female & 55 & 1.927 & .87886 & .11851 \\
& & & 3 & & \\
& Male & 79 & 2.493 & 1.01114 & .11376 \\
Pre2 & & & 7 & & \\
& Female & 55 & 1.872 & .74671 & .10069 \\
& & & 7 & & \\
Pre3 & Male & 79 & 2.531 & .90349 & .10165 \\
& & & 6 & &
\end{tabular}




\begin{tabular}{|c|c|c|c|c|c|}
\hline & Female & 55 & $\begin{array}{r}2.254 \\
5\end{array}$ & .88649 & .11953 \\
\hline \multirow{2}{*}{ Pre4 } & Male & 79 & $\begin{array}{r}2.860 \\
8\end{array}$ & .95722 & .10770 \\
\hline & Female & 55 & $\begin{array}{r}3.181 \\
8\end{array}$ & 1.23365 & .16634 \\
\hline \multirow{2}{*}{ Pre5 } & Male & 79 & $\begin{array}{r}2.734 \\
2\end{array}$ & 1.00905 & .11353 \\
\hline & Female & 55 & $\begin{array}{r}2.254 \\
5\end{array}$ & 1.12576 & .15180 \\
\hline \multirow{2}{*}{ pre6 } & Male & 79 & $\begin{array}{r}2.506 \\
3\end{array}$ & 1.02374 & .11518 \\
\hline & Female & 55 & $\begin{array}{r}3.309 \\
1\end{array}$ & 1.06931 & .14419 \\
\hline \multirow{2}{*}{ pre7 } & Male & 79 & $\begin{array}{r}2.797 \\
5\end{array}$ & .88259 & .09930 \\
\hline & Female & 55 & $\begin{array}{r}3.072 \\
7\end{array}$ & 1.28891 & .17380 \\
\hline \multirow{2}{*}{ pre8 } & Male & 79 & $\begin{array}{r}2.113 \\
9\end{array}$ & 1.17656 & .13237 \\
\hline & Female & 55 & $\begin{array}{r}1.727 \\
3\end{array}$ & .82674 & .11148 \\
\hline \multirow{2}{*}{ pre9 } & Male & 79 & $\begin{array}{r}2.620 \\
3\end{array}$ & .93786 & .10552 \\
\hline & Female & 55 & $\begin{array}{r}2.454 \\
5\end{array}$ & .93923 & .12665 \\
\hline \multirow{2}{*}{ pre10 } & Male & 79 & $\begin{array}{r}2.708 \\
9\end{array}$ & .89374 & .10055 \\
\hline & Female & 55 & $\begin{array}{r}2.345 \\
5\end{array}$ & .90714 & .12232 \\
\hline \multirow{2}{*}{ pre11 } & Male & 79 & $\begin{array}{r}2.569 \\
6\end{array}$ & .88699 & .09979 \\
\hline & Female & 55 & $\begin{array}{r}2.290 \\
9\end{array}$ & .71162 & .09595 \\
\hline \multirow{2}{*}{ pre12 } & Male & 79 & $\begin{array}{r}2.936 \\
7\end{array}$ & .82185 & .09246 \\
\hline & Female & 55 & $\begin{array}{r}3.163 \\
6\end{array}$ & 1.16688 & .15734 \\
\hline \multirow{2}{*}{ pre13 } & Male & 79 & $\begin{array}{r}2.734 \\
2\end{array}$ & .88736 & .09984 \\
\hline & Female & 55 & $\begin{array}{r}2.345 \\
5\end{array}$ & 1.00403 & .13538 \\
\hline \multirow{2}{*}{ pre14 } & Male & 79 & $\begin{array}{r}2.658 \\
2\end{array}$ & 1.13099 & .12725 \\
\hline & Female & 55 & $\begin{array}{r}2.818 \\
2\end{array}$ & 1.10706 & .14928 \\
\hline
\end{tabular}




\begin{tabular}{|c|c|c|c|c|c|}
\hline \multirow{2}{*}{ pre15 } & Male & 79 & $\begin{array}{r}2.354 \\
4\end{array}$ & .93422 & .10511 \\
\hline & Female & 55 & $\begin{array}{r}2.145 \\
5\end{array}$ & 1.02593 & .13834 \\
\hline \multirow{2}{*}{ pre16 } & Male & 79 & $\begin{array}{r}3.202 \\
5\end{array}$ & 1.13657 & .12787 \\
\hline & Female & 55 & $\begin{array}{r}3.690 \\
9\end{array}$ & 1.18435 & .15970 \\
\hline \multirow{2}{*}{ pre17 } & Male & 79 & $\begin{array}{r}2.848 \\
1\end{array}$ & .94853 & .10672 \\
\hline & Female & 55 & $\begin{array}{r}2.436 \\
4\end{array}$ & 1.04993 & .14157 \\
\hline \multirow{2}{*}{ pre18 } & Male & 79 & $\begin{array}{r}2.215 \\
2\end{array}$ & .99577 & .11203 \\
\hline & Female & 55 & $\begin{array}{r}1.909 \\
1\end{array}$ & .82266 & .11093 \\
\hline \multirow{2}{*}{ pre19 } & Male & 79 & $\begin{array}{r}2.670 \\
9\end{array}$ & 1.17366 & .13205 \\
\hline & Female & 55 & $\begin{array}{r}2.181 \\
8\end{array}$ & .88382 & .11917 \\
\hline \multirow{2}{*}{ pre20 } & Male & 79 & $\begin{array}{r}2.443 \\
0\end{array}$ & .97068 & .10921 \\
\hline & Female & 55 & $\begin{array}{r}2.290 \\
9\end{array}$ & .99392 & .13402 \\
\hline \multirow{2}{*}{ pre21 } & Male & 79 & $\begin{array}{r}2.708 \\
9\end{array}$ & 1.02722 & .11557 \\
\hline & Female & 55 & $\begin{array}{r}2.163 \\
6\end{array}$ & .83364 & .11241 \\
\hline \multirow{2}{*}{ pre22 } & Male & 79 & $\begin{array}{r}2.531 \\
6\end{array}$ & .98496 & .11082 \\
\hline & Female & 55 & $\begin{array}{r}1.945 \\
5\end{array}$ & .93131 & .12558 \\
\hline \multirow{2}{*}{ pre23 } & Male & 79 & $\begin{array}{r}2.544 \\
3\end{array}$ & .91704 & .10317 \\
\hline & Female & 55 & $\begin{array}{r}1.872 \\
7\end{array}$ & .69534 & .09376 \\
\hline \multirow{2}{*}{ pre24 } & Male & 79 & $\begin{array}{r}2.544 \\
3\end{array}$ & .99740 & .11222 \\
\hline & Female & 55 & $\begin{array}{r}2.054 \\
5\end{array}$ & .97026 & .13083 \\
\hline \multirow{2}{*}{ pre25 } & Male & 79 & $\begin{array}{r}2.582 \\
3\end{array}$ & 1.06948 & .12033 \\
\hline & Female & 55 & $\begin{array}{r}2.018 \\
2\end{array}$ & .99053 & .13356 \\
\hline pre26 & Male & 79 & $\begin{array}{r}2.417 \\
7\end{array}$ & .95552 & .10750 \\
\hline
\end{tabular}




\begin{tabular}{|c|c|c|c|c|c|}
\hline & Female & 55 & $\begin{array}{r}1.800 \\
0\end{array}$ & .82552 & .11131 \\
\hline \multirow{2}{*}{ pre27 } & Male & 79 & $\begin{array}{r}2.405 \\
1\end{array}$ & .91314 & .10274 \\
\hline & Female & 55 & $\begin{array}{r}2.163 \\
6\end{array}$ & .87694 & .11825 \\
\hline \multirow{2}{*}{ pre28 } & Male & 79 & $\begin{array}{r}2.506 \\
3\end{array}$ & 1.20760 & 13587 \\
\hline & Female & 55 & $\begin{array}{r}1.800 \\
0\end{array}$ & .82552 & .11131 \\
\hline \multirow{2}{*}{ pre29 } & Male & 79 & $\begin{array}{r}2.506 \\
3\end{array}$ & .97235 & 10940 \\
\hline & Female & 55 & $\begin{array}{r}1.963 \\
6\end{array}$ & .79264 & .10688 \\
\hline \multirow{2}{*}{ pre30 } & Male & 79 & $\begin{array}{r}2.544 \\
3\end{array}$ & .93091 & .10474 \\
\hline & Female & 55 & $\begin{array}{r}1.909 \\
1\end{array}$ & .88763 & .11969 \\
\hline \multirow{2}{*}{ pre31 } & Male & 79 & $\begin{array}{r}2.468 \\
4\end{array}$ & 1.02326 & .11513 \\
\hline & Female & 55 & $\begin{array}{r}2.018 \\
2\end{array}$ & .82756 & .11159 \\
\hline
\end{tabular}

Male $(\mathrm{M}=2.67, \mathrm{SD}=1.17)$ and Female $(\mathrm{M}=2.18, \mathrm{SD}=0.88) \mathrm{t}(132)=2.616, \mathrm{p}=.011$. However Post- Test analysis of Question 19 reveals no significance difference between males and females. Male $(\mathrm{M}=2.38, \mathrm{SD}=1.11)$ and Female $(\mathrm{M}=2.20, \mathrm{SD}=1.10) \mathrm{t}(132)=0.925, \mathrm{p}=0.340$.

An Independent T-Test analysis was conducted for the Reading Strategy Questionnaire. The analysis revealed gender differences for the Reading Strategy. Male $(\mathrm{M}=2.62, \mathrm{SD}=0.599)$ Female $(\mathrm{M}=2.42, \mathrm{SD}=0.367) \mathrm{t}(132)=2.23, \mathrm{p}=0.000$ (See Table 14).

Table 14. Gender differences: Reading Strategy Questionnaire

\begin{tabular}{lllccc}
\hline & Gender & $\mathrm{N}$ & Mean & Std Deviation & Std Error Mean \\
\hline $\begin{array}{l}\text { Mean } \\
\text { RS }\end{array}$ & Male & 79 & 2.6228 & .59894 & .06739 \\
& Female & 55 & 2.4206 & .36602 & .04935 \\
\hline
\end{tabular}

Female participants were more likely to strongly agree with Question 1, "I know this topic", Male (M=2.67, SD= 1.140), Female $(\mathrm{M}=2.16, \mathrm{SD}=0.834)$ and Question 2; "I like to share ideas about the topic." $\mathrm{Male}(\mathrm{M}=3.01, \mathrm{SD}=$ 1.27), Female $(\mathrm{M}=2.27, \mathrm{SD}=0.859)$. However question 5 females did not agree with the statement "I have problems getting the main ideas or concepts." Male $(\mathrm{M}=2.27, \mathrm{SD}=1.08)$, females $(\mathrm{M}=3.01, \mathrm{SD}=1.12)$. ( See Table 15).

Question 6 asked if participants “... have problems finding the supporting details to the main idea" Males ( M=2.72, $\mathrm{SD}=1.14)$,females $(\mathrm{M}=3.24, \mathrm{SD}=1.00)$. Again females were less likely to agree with this statement. As they were with question 7, "I have problems understanding structure/grammar. "Male $(\mathrm{M}=2.85, \mathrm{SD}=1.17)$ female $(\mathrm{M}=3.60$, $\mathrm{SD}=1.08$ ). Question 10: "looking for prefixes or suffixes in the word is useful." Female participants strongly agreed with this statement demonstrating an understanding of the material. Male $(\mathrm{M}=2.58, \mathrm{SD}=1.01)$, Female $(\mathrm{M}=1.96, \mathrm{SD}=0.88)$. (see Table15).

Question 11 asked, "Break the word apart and look for smaller words is useful." Females were to statistically significantly agree with this statement then male, again illustrating their application and ability to utilize the Reading Strategy lesson. Male $(\mathrm{M}=2.85, \mathrm{SD}=1.32)$, Female $(\mathrm{M}=2.18, \mathrm{SD}=1.02)$. Lastly for Question 12, "I can restate the main idea in my own words" females were found to statistically significantly agree with question 12 then male participants. Males $(\mathrm{M}=2.63, \mathrm{SD}=1.01)$, Females $(\mathrm{M}=2.02, \mathrm{SD}=0.73)$. (see Table 15). 
Table 15. Group Statistics for Reading Strategy

Group Statistics

\begin{tabular}{|c|c|c|c|c|c|}
\hline & Gender & $\mathrm{N}$ & Mean & Std. Deviation & Std. Error Mean \\
\hline \multirow{2}{*}{ RS1 } & male & 79 & 2.6709 & 1.14042 & .12831 \\
\hline & female & 55 & 2.1636 & .83364 & .11241 \\
\hline \multirow{2}{*}{$\mathrm{RS} 2$} & male & 79 & 3.0127 & 1.26586 & .14242 \\
\hline & female & 55 & 2.2727 & .84885 & .11446 \\
\hline \multirow{2}{*}{$\mathrm{RS} 3$} & male & 79 & 2.5823 & .88590 & .09967 \\
\hline & female & 55 & 2.1273 & .90379 & .12187 \\
\hline \multirow{2}{*}{ RS4 } & male & 79 & 2.4304 & 1.04616 & .11770 \\
\hline & female & 55 & 2.4545 & .87809 & .11840 \\
\hline \multirow{2}{*}{ RS5 } & male & 79 & 2.8734 & 1.07854 & .12135 \\
\hline & female & 55 & 3.2182 & 1.11705 & .15062 \\
\hline \multirow{2}{*}{ RS6 } & male & 79 & 2.7215 & 1.14283 & .12858 \\
\hline & female & 55 & 3.2364 & .99933 & .13475 \\
\hline \multirow{2}{*}{ RS7 } & male & 79 & 2.8481 & 1.16672 & .13127 \\
\hline & female & 55 & 3.6000 & 1.08184 & .14587 \\
\hline \multirow{2}{*}{ RS8 } & male & 79 & 2.2658 & 1.14028 & .12829 \\
\hline & female & 55 & 2.5091 & 1.13648 & .15324 \\
\hline \multirow{2}{*}{ RS9 } & male & 79 & 2.2532 & .95365 & .10729 \\
\hline & female & 55 & 2.0545 & .97026 & .13083 \\
\hline \multirow{2}{*}{ RS10 } & male & 79 & 2.5823 & 1.00776 & .11338 \\
\hline & female & 55 & 1.9636 & .88115 & .11881 \\
\hline \multirow{2}{*}{ RS11 } & male & 79 & 2.8481 & 1.32131 & .14866 \\
\hline & female & 55 & 2.1818 & 1.02000 & .13754 \\
\hline \multirow{2}{*}{ RS12 } & male & 79 & 2.6329 & 1.01498 & .11419 \\
\hline & female & 55 & 2.0182 & .73260 & .09878 \\
\hline \multirow{2}{*}{ RS13 } & male & 79 & 2.3924 & .95297 & .10722 \\
\hline & female & 55 & 2.0909 & 1.07622 & .14512 \\
\hline \multirow{2}{*}{ RS14 } & male & 79 & 2.5696 & 1.08230 & .12177 \\
\hline & female & 55 & 2.2182 & 1.18151 & .15931 \\
\hline \multirow{2}{*}{ RS15 } & male & 79 & 2.6582 & 1.10808 & .12467 \\
\hline & female & 55 & 2.2000 & 1.00738 & .13584 \\
\hline
\end{tabular}

4. Limitations of the study

Discrepancies found in the effectiveness of the Reading Strategy lesson and Post-Reading strategy results may be contributed by many factors. The limitations can result from time restraints given to the participants. As students had limited exposure to the Reading Strategy lesson, the application of the tools learned could not be applied in such a 
short time frame. Perhaps many lessons on the Reading Strategy could result in a statistical significant output. Another contributing factor to this study's limitations could be the length of the study. Participants were required to complete three questionnaires and partook in a lesson on reading strategies. Perhaps if the study was expanded over a longer period of time with more lessons on reading strategies, the study would have yielded statistically significant results.

Another limitation to the study is participant size and demographic. The subjects of this study were all University Students in the same University, approximately the same age and speak English as their second language. These factors may have played a role in the results of this study. In addition, the sample size was relatively small $(\mathrm{N}=134)$ with 79 male participants and 55 female. Perhaps a larger study with more diversity in participants would have yielded different results.

Gender differences also may have had an effect on the results. Further analysis of the data revealed an interesting pattern in how females responded to the questionnaires. Female responses were more likely to correlate with a positive self image, as discussed in the results section. Male participants however were more subtle and neutral in their responses, not having a high self image or a low one. Female means for each category of the Reading Strategy Questionnaire were lower (Agreeing more) for each category except finding the supporting details. This may implicate a lack of applied knowledge.

Although we reject our null hypothesis and found no significance between the Pre-Reading Strategy and Post-Reading Strategy, we were able to notice a gender difference in responses. Females were more likely to utilize the tools given to them during the Reading Strategy Lesson then the male participants.

\section{Conclusion}

The purpose of this present study was to examine the effect of CSR on Taif University students' reading comprehension with reference to specific types of reading comprehension questions. This study has given insight to educators on how male and female students process and learn differently. Although we reject the alternative hypothesis and conclude that the Reading Strategy Survey was not effective at 5\% significance level. Pre-Reading Strategy Test $(M=2.517, S D=0.453)$ and Post Reading Strategy test $(M=2.452, S D=466) t=(133)=1.628, p=0.106$, we are able to adjust our teaching methods to better accommodate gender differences in learning. Future research should focus not only a longer exposure to the Reading Strategy tools, but on how to present these tools differently to males and female.

\section{References}

Chen, J. C. (2005). Explicit instruction of reading strategies at senior high school in Taiwan. National Kaohsiung Normal University. Kaohsiung, Taiwan.

Colorado Department of Education. (2012). Collaborative Strategic Reading (CSR) lesson plans. retrieved from http://www.csrcolorado.org/en/educators/sample-lesson-plans/

Cotterall, S. (1990). Developing reading strategies through small-group interaction. RELC Journal, 21(2), 55-69. Efficacy of Collaborative Strategic Reading with Middle School Students. http://dx.doi.org/10.1177/003368829002100205

Huang, C. Y. (2004). Think to win: An inquiry-based approach via Collaborative Strategic Reading technique to teach English reading in a senior high EFL classroom. National Taiwan Normal University, Taipei, Taiwan.

Janzen, J., \& Stoller, F. L. (1998). Integrating strategic reading in L2 instruction. Reading in a Foreign Language, 12(1), 251-268.

Klingner, J. K., Vaughn, S., \& Schumm, J. S. (1998). Collaborative strategic reading during social studies in heterogeneous fourth-grade classrooms. The Elementary School Journal, 99, 3-22. http://dx.doi.org/10.1086/461914

Klingner,J.,Vaugn,S., Arguelles, M., Hughes, M., \& Leftwich, S. (2004). Collaborative Strategic Reading: "Real-World" Lessons From Classroom Teachers. Remedial and Special Education, 25(5), 291-302. http://dx.doi.org/10.1177/07419325040250050301

Koda, K. (2004). Insights into second language reading: A cross-linguistic approach. Cambridge: Cambridge University Press.

Lee, C. I. (2003). Promoting reading comprehension ability and vocabulary learning through Collaborative Strategic Reading. National Taipei Teachers College, Taipei, Taiwan. 
Lenski, S. D., \& Nierstheimer, S. L. (2002). Strategy instruction from a sociocognitive perspective. Reading Psychology, 23, 127-143. http://dx.doi.org/10.1080/027027102760351034

Loranger, A. L. (1997). Comprehension strategies instruction: Does it make a difference? Reading Psychology, 18, 31-68. http://dx.doi.org/10.1080/0270271970180102

Palincsar, A. S., \& Brown, A. L. (1984). Reciprocal teaching of comprehension-fostering and Paris, S. G., Lipson, M. Y., \& Wixson, K. K. (1983). Becoming a strategic reader. Contemporary Educational Psychology, 8, 293-316.

Pressley, M. (2002). Comprehension strategies instruction: A turn-of-the-century status report. In C. C. Block \& M. Pressley (Eds.), Comprehension instruction: Research-based best practices . New York: The Guilford Press.

Pressley, M. (2006). Reading instruction that works: The case for balanced teaching (3rd ed.). New York: The Guilford Press.

Pressley, M., El-Dinary, P. B., Gaskins, I., Schuder, T., Bergman, J., Almasi, J., et al. (1992). Beyond direct explanation: Transactional instruction of reading comprehension strategies. Elementary School Journal, 92, 511-554. http://dx.doi.org/10.1086/461705

Roehler, L.R, \& Duffy, G. G. (1984). Direct explanation of comprehension process. In G. G. Duffy, L. R. Roehler \& J. Mason (Eds.), Comprehension instruction: Perspectives and suggestions (pp. 265-280). New York: Longman.

Rosenshine, B., \& Meister, C. (1994). Reciprocal teaching: A review of the research. Review of Educational Research, 64, 479-530. http://dx.doi.org/10.3102/00346543064004479

Sharon, V., Janette K. Klingner, J., K., Swanson, Boardman, E., A., Roberts, G., et al (2011).

Song, M. J. (1998). Teaching reading strategies in an ongoing EFL university reading classroom. American Educational Research Journal. Vol. 48, No. 4,pp. 938-964. http://dx.doi.org/10.3102/0002831211410305

Standish, L. G. (2005). The effects of Collaborative Strategic Reading and direct Instruction in persuasion on sixth-grade students' persuasive writing and attitudes. Maryland :University of Maryland, College Park.

Wang, T. H. (2008). The effects of modified Collaborative Strategic Reading on EFL learners' reading comprehension. National Changhua. University of Education, Chunghwa.

Taiwan. Zwier, L. J., \& Stafford-Yilmaz, L. (2004). Reading for the real world 2. New York: Compass Publishing. 